\title{
Prescribed burning in a mediterranean- climate region mitigates the disturbance by bushfire to a critical food resource for an endangered bird, the Carnaby's cockatoo
}

\author{
Valerie S. Densmore ${ }^{1 *}$ and Emma S. Clingan ${ }^{2}$
}

\begin{abstract}
Background: Prescribed burning is used to reduce fire hazard in highly flammable vegetation types, including Banksia L.f. woodland that occurs on the Swan Coastal Plain (SCP), Western Australia, Australia. The 2016 census recorded well over 1.9 million people living on the SCP, which also encompasses Perth, the fourth largest city in Australia. Banksia woodland is prone to frequent ignitions that can cause extensive bushfires that consume canopystored banksia seeds, a critical food resource for an endangered bird, the Carnaby's cockatoo (Calyptorynchus latirostris, Carnaby 1948). The time needed for banksias to reach maturity and maximum seed production is several years longer than the typical interval between prescribed burns. We compared prescribed burns to bushfires and unburned sites at three locations in banksia woodland to determine whether low-intensity prescribed burns affect the number of adult banksias and their seed production. Study sites were matched to the same vegetation complex, fire regime, and timesince-fire to isolate fire intensity as a variable.

Results: Headfire rates of spread and differenced normalized burn ratios indicated that prescribed burning was generally of a much lower intensity than bushfire. The percentage survival of adult banksias and their production of cones and follicles (seeds) did not decrease during the first three years following a prescribed burn. However, survival and seed production were significantly diminished followed high-intensity bushfire. Thus, carrying capacity for Carnaby's cockatoo was unchanged by prescribed burning but decreased markedly following bushfire in banksia woodland.
\end{abstract}

Conclusions: These results suggest that prescribed burning is markedly different from bushfire when considering appropriate fire intervals to conserve canopy habitats in fire-resilient vegetation communities. Therefore, low-intensity prescribed burning represents a viable management tool to reduce the frequency and extent of bushfire impacts on banksia woodland and Carnaby's cockatoo.

Keywords: Australia, banksia woodland, Carnaby's cockatoo, fire intensity, fire regime, mediterranean-climate region, prescribed burning, time-since-fire

\footnotetext{
* Correspondence: Valerie.Densmore@dbca.wa.gov.au

${ }^{1}$ Department of Biodiversity, Conservation and Attractions, Manjimup

Research Centre, Locked Bag 2, Manjimup, Western Australia 6258, Australia

Full list of author information is available at the end of the article
} 


\section{Resumen}

Antecedentes: La quema prescrita es usada para reducir el peligro de incendios en tipos de vegetación altamente inflamable, incluyendo los matorrales de Banksia L.f que se encuentran en las planicies de la costa (Swan Coastal Plain, SCP), en el territorio del oeste de Australia. El censo de 2016 registró por encima de 1.9 millones las personas que viven en esas planicies (SCP), que también incluyen a Perth, la cuarta ciudad más grande de Australia. El matorral de banksia es proclive a igniciones frecuentes que causan fuegos extensos en esos matorrales y que consumen las semillas de banksia almacenadas en su dosel. Estas semillas son un recurso alimenticio crítico para una especie de pájaro amenazado, la cacatúa de pico corto (Calyptorynchus latirostris, Carnaby 1948). El tiempo necesario para que las plantas de banksia lleguen a su madurez y a su máxima producción de semillas es mucho más largo que el intervalo típico entre quemas prescritas. Comparamos sitios sometidos a quemas prescritas con otros no quemados en tres ubicaciones en matorrales de banksia, para determinar si las quemas prescritas de baja intensidad afectan el número de adultos de banksia y su producción de semillas. Los sitios eran comparables en cuanto a complejos de vegetación, regímenes de fuego y el tiempo desde el último fuego, para poder aislar la intensidad del fuego como variable.

Resultados: La tasa de fuegos frontales y la relación diferencial normalizada de la tasa de quema (differenced normalized burn ratios) indicaron que las quemas prescritas fueron generalmente de mucha menor intensidad que la de incendios naturales. El porcentaje de supervivencia de plantas adultas de banksia y su producción de conos y folículos (semillas), no decreció durante los tres años posteriores a la quema prescrita. Sin embargo, la producción de semillas fue significativamente disminuida en estos matorrales luego de incendios de alta intensidad. La capacidad de carga para la cacatúa de pico corto no fue entonces disminuida por las quemas prescritas, pero decrecieron marcadamente luego de incendios naturales en estos matorrales de banksia.

Conclusiones: Estos resultados sugieren que las quemas prescritas son marcadamente diferentes en relación con los incendios naturales de estos matorrales cuando se consideran intervalos de fuego apropiados para conservar hábitat en el dosel de comunidades vegetales resilientes al fuego. Esto indica que las quemas prescritas de baja intensidad representan un herramienta de manejo viable para reducir la frecuencia y extensión de los impactos del fuego en los matorrales de banksia y en la cacatúa de pico corto.

\section{Abbreviations}

DBCA: Department of Biodiversity, Conservation and Attractions, Western Australia

est: estimated coefficient

MCR: mediterranean-climate region

$\triangle$ NBR: differenced Normalized Burn Ratio

NBR: Normalized Burn Ratio

NR: Nature Reserve

PB: Prescribed Burn

SCP: Swan Coastal Plain

SF: State Forest

\section{Background}

Mediterranean-climate regions (MCRs) have proportionally high levels of biodiversity and endemism encompassed within relatively flammable ecosystems. The five MCRs include the Mediterranean basin, southwestern Australia, the Cape Region of South African, central Chile, and parts of California and northern Baja California, and these collectively occupy less than $5 \%$ of the world's surface area but contain around 20\% of the earth's flora (Cowling et al. 1996). The characteristic MCR climate includes cool wet winters and warm dry summers. This cyclical pattern promotes vegetation growth followed by an extended drying period and facilitates the regular occurrence of bushfires or wildfires (Keeley 1986; McCaw and Hanstrum 2003; Syphard et al. 2009; Van Wilgen et al. 2010). Given the inevitability of fire in MCRs, most plant species exhibit traits that promote their persistence, including resprouting from heat-shielded buds and germinating from seed stored in the soil or canopy. Both resprouter and seeder strategies facilitate resilience, but the relative benefit provided by either response depends on the fire regime (Gill 1978; Keeley 1986).

The term "resilience" captures how rapidly an ecosystem component returns to a pre-disturbance level or state (Lavorel 1999). The amplitude of a disturbance, or its severity, directly affects how much time is needed for recovery. The severity of any given fire depends on how closely it aligns to the fire regime, which includes the intensity, frequency, extent, and season when fire typically occurs in that ecosystem (Whelan 1995; Keeley 2009). These four components interact to influence fuel availability and fire behavior. Recent studies that have included fire severity as well as time-since-fire (AKA frequency) have found nuanced effects on the resilience of bird population sizes and distributions. Species richness declined in areas that experienced high-severity fire (Fontaine and Kennedy 2012; Lindenmayer et al. 2014), but the magnitude of change in relative bird abundance 
was also related to time-since-fire (Smucker et al. 2005; Lindenmayer et al. 2014; Hutto and Patterson 2016) and habitat preferences (Fontaine and Kennedy 2012; Hutto and Patterson 2016). These studies have important implications for fire management, particularly in the use of prescribed burning to mitigate the risk of bushfire to resources upon which threatened species, such as Carnaby's cockatoo (Calyptorynchus latirostris, Carnaby 1948), depend.

Carnaby's cockatoo is a gregarious black cockatoo endemic to south-west Western Australia. Recorded numbers of Carnaby's cockatoo are estimated to have decreased by up to $50 \%$ over the past 45 years, and the species is currently listed as endangered under Australian State and Commonwealth legislation (Shah 2006). A key factor threatening the viability of remaining populations is reduced food availability due to the loss and fragmentation of habitat and frequent bushfires (Shah 2006; Valentine et al. 2014; Stock et al. 2013; Williams et al. 2017). During the non-breeding season, flocks migrate to banksia woodland to feed on a number of serotinous species. Historically, over $50 \%$ of the diet for Carnaby's cockatoo has been high-energy seeds from Banksia attenuata R.Br and B. menziesii R.Br (Saunders 1980; Cowling et al. 1987; Cooper et al. 2002; Shah 2006), but is increasingly supplemented with non-native pine seed as $B$. attenuata and $B$. menziesii become less available due to land-use change (Stock et al. 2013; Johnston et al. 2016). Both B. menziesii and $B$. attenuata annually produce flowers and infructescences (Johnston 2013; Valentine et al. 2014), which are weakly serotinous in banksia woodland and release the majority of their seed within 2 and 3.5 years of production, respectively, without requiring a fire cue (Cowling and Lamont 1985). This characteristic allows these species to recruit new individuals during the inter-fire interval, but it also means that fruiting must not be interrupted by canopy scorch if they are to provide a steady food source for Carnaby's cockatoo (Lamont 1985; Cowling et al. 1987; Hobbs and Atkins 1990; Wooller and Wooller 2001).

In 2016, Banksia Woodland of the Swan Coastal Plain was listed as endangered under Australian Commonwealth legislation due to vegetation clearing and significant fragmentation for land-use changes that included Perth, the fourth-largest city in Australia (Threatened Species Scientific Committee 2016). The proximity to a large human population has increased the frequency of bushfires (Syphard et al. 2009). Banksia woodland typifies an MCR as a highly flammable vegetation community with mild, wet winters and hot, dry summers (Burrows and McCaw 1990). The compact vertical structure of this woodland includes an open overstory approximately 5 to $8 \mathrm{~m}$ tall over a moderately dense elevated (shrub) layer that contains 20 to $50 \%$ fine dead fuel and relatively light and patchy surface (litter) fuels (Baird 1977; Burrows and McCaw 1990; Hobbs and
Atkins 1990). This fuel arrangement requires moderate wind speeds to sustain fire spread, and headfire rates of spread are directly proportional to wind speed. Under extreme weather conditions, bushfires in banksia woodland can reach intensities well above $10000 \mathrm{~kW} \mathrm{~m}^{-1}$, consuming nearly all the foliage and a high proportion of the aboveground biomass, and killing some of the overstory (Baird 1977; Wilson et al. 2010; Brundrett et al. 2018). Following a bushfire, most tree species in banksia woodland are able to resprout from stem epicormic shoots (Baird 1977; Hobbs and Atkins 1990), and fuel loads recover after approximately four to six years (Baird 1977; Burrows and McCaw 1990). Recent studies have suggested that $B$. attenuata and $B$. menziesii require 10 to 30 years after fire to reach optimum seed production in banksia woodland (Valentine et al. 2014; Wilson et al. 2014; Johnston et al. 2016), but these studies did not examine whether there were interactions between fire intensity and time-since-fire. Therefore, it remains unclear whether fire intensity affects the resilience of B. attenuata and B. menziesii seed production.

Prescribed burning is used in banksia woodland to apply low-intensity fire at select frequencies and seasons. A primary intent of prescribed burning is to mitigate risks due to bushfire, but it also provides an opportunity to maintain a fire regime that facilitates the resilience of threatened or endemic species. The Department of Biodiversity, Conservation and Attractions in Western Australia (DBCA, formerly Department of Parks and Wildlife) prescribes burns in banksia woodland to achieve average fire intensities below $350 \mathrm{~kW} \mathrm{~m}^{-1}$. These limits are considered sufficient to allow most adult banksias to retain their crowns and continue producing seeds for Carnaby's cockatoo. However, it has not been explicitly tested whether low-intensity prescribed burns affect survival or seed production for B. attenuata or B. menziesii.

Between 2014 and 2016, three bushfires in banksia woodland occurred near areas that had undergone prescribed burning in the preceding two to eight months. The temporal and spatial proximity of these fires provided an opportunity to compare the effects of high-intensity, low-intensity, and no fire in areas that otherwise had a consistent vegetation profile and fire regime. Using these areas, the broad aim of this study was to determine if fire intensity affected the resilience of seed production by $B$. attenuata and $B$. menziesii. Three hypotheses were posed to address this aim: (1) more adult $B$. attenuata and B. menziesii would survive a low-intensity prescribed burn than a high-intensity bushfire; (2) prescribed burning would have a lower amplitude of disturbance to cone production than bushfire; and (3) seed production would recover to long-unburned levels at a faster rate after a prescribed burn compared to a bushfire. 


\section{Methods}

\section{Study area}

The study areas were located between 50 and $100 \mathrm{~km}$ north of Perth, Western Australia, Australia, in the ecological community of Banksia Woodland on the Swan Coastal Plain. All study areas fell within the Bassendean Complex-North on aeolian sands, elevation between 55 to 80 meters above sea level and mean daily maximum temperatures ranging from $17.9{ }^{\circ} \mathrm{C}$ in July to $33.5{ }^{\circ} \mathrm{C}$ in January. All of the areas contained low woodland dominated by Banksia species, occasional small stands of Eucalyptus todtiana F. Muell., and understory species primarily from the Fabaceae, Myrtaceae, and Proteaceae families (Heddle et al. 1980). The region occurs within the Gnangara Groundwater System and experiences a mediterraneantype climate with average annual rainfall around $650 \mathrm{~mm}$, $80 \%$ of which falls during the cooler months of May through September. Annual rainfall has declined markedly over the past 30 years (Bates et al. 2008), and urban development has decreased both groundwater levels and the area occupied by native vegetation.

Three separate areas were identified containing sites that were unburned or had experienced a prescribed burn or bushfire within two to eight months of each other. The three areas containing grouped unburned, prescribed burn, and bushfire study sites were located in: (1) Moore River Nature Reserve (Moore River NR), (2) Caraban State Forest (Caraban SF), and (3) Yeal Nature Reserve (Yeal NR) (Fig. 1). Vegetation distribution, fire history records, and three-year burn plans were sourced from DBCA and used with ArcMap version 10.3.1. Vegetation complexes were classified as banksia woodland according to Heddle et al. (1980).

Recorded fire histories dating back to 1966 were compiled for each site using ArcMap and the assumption that areas of interest were actually burned at the time depicted by the recorded fire histories. The average interval and total and median season and event type for each area is provided in Table 1 . In each study area, the prescribed-burn and bushfire sites had experienced the same antecedent prescribed burn or bushfire prior to the most recent event under investigation in this study. The average fire intervals differed by five months to two years, and the total number of events or number of events per season were matched to between zero to two among grouped sites. When areas were compared, average fire interval ranged between 8.2 to $14 \mathrm{yr}$, and the median type and season were either a spring prescribed burn (Yeal NR) or summer bushfire for the other areas. The similarities facilitated isolating fire intensity as a variable within each area, but the differences between areas would potentially exert a statistical effect that was addressed by setting up the experiment as a repeated measures analysis.

\section{Fire behavior parameters}

Table 2 lists the forecast weather conditions, headfire rates of spread, range of fire intensities, and available fuel weight on the day each bushfire or prescribed burn commenced. Litter depth, average height of shrubs, and percentage of suspended dead fine fuel was measured at $10 \mathrm{~m}$ intervals along four to seven $100 \mathrm{~m}$ transects. Fuel weight was the sum total of litter fuels, calculated using Sneeuwjagt and Peet's (1985) tabulated values for litter depth and vegetation type 6 , and shrub fuels, calculated using tabular values for shrub height and density in vegetation type 6 (Sneeuwjagt and Peet 1985; Burrows and McCaw 1990). Headfire rates of spread were directly measured and recorded by fire operations staff at each prescribed burn and bushfire. The range of intensities was calculated according to Byram (1959) using the formula $I=H w R$, where $w=$ weight of fuel consumed per unit area $\left(\mathrm{kg} \mathrm{m}^{-2}\right)$, $R=$ headfire rate of spread $\left(\mathrm{m} \mathrm{s}^{-1}\right)$, and $H=$ heat of combustion $\left(\mathrm{kJ} \mathrm{kg}^{-1}\right)$, standardized to $0.5 \mathrm{~kJ} \mathrm{~kg}^{-1}$.

\section{Prescribed burn versus bushfire severity analyses}

Landsat 8 satellite imagery was accessed from https:// libra.developmentseed.org. Images were chosen close to one month after the bushfire and one year prior to the post-fire-image, subject to images from the desired timeframe being free from cloud cover. Band 7 (shortwave infrared 2) and band 5 (near infrared) were used in ArcMap 10.6.1 to calculate the normalized burn ratio (NBR) using the following formula:

$$
N B R=\frac{\text { band } 5-\text { band } 7}{\text { band } 5+\text { band } 7}
$$

The NBR calculated for the pre-fire image was then subtracted from the post-fire NBR to determine the differenced NBR $(\triangle \mathrm{NBR})$, which normalizes the results for different reflectivity associated with varying landforms and vegetation or soil types (Walz et al. 2007). Due to the time differences between prescribed burn and bushfire events used for this study, ground-truthing of the $\triangle \mathrm{NBR}$ results were not feasible. Instead, pixels were classified simultaneously for the fire, burn, and unburned sites within each area using Jenks natural breaks algorithm (Jenks 1967). Consequently, comparisons could be made across the $\triangle \mathrm{NBR}$ values for sites within each area. The pixel differentials for each plot were determined using the extraction by points tool in ArcMap.

\section{Assessing seed production}

Sites were assessed in January of 2017, 2018, and 2019. The prescribed burn and bushfire had occurred one year earlier in Moore River NR than Caraban SF and Yeal NR, so three consecutive years of data collection 
a

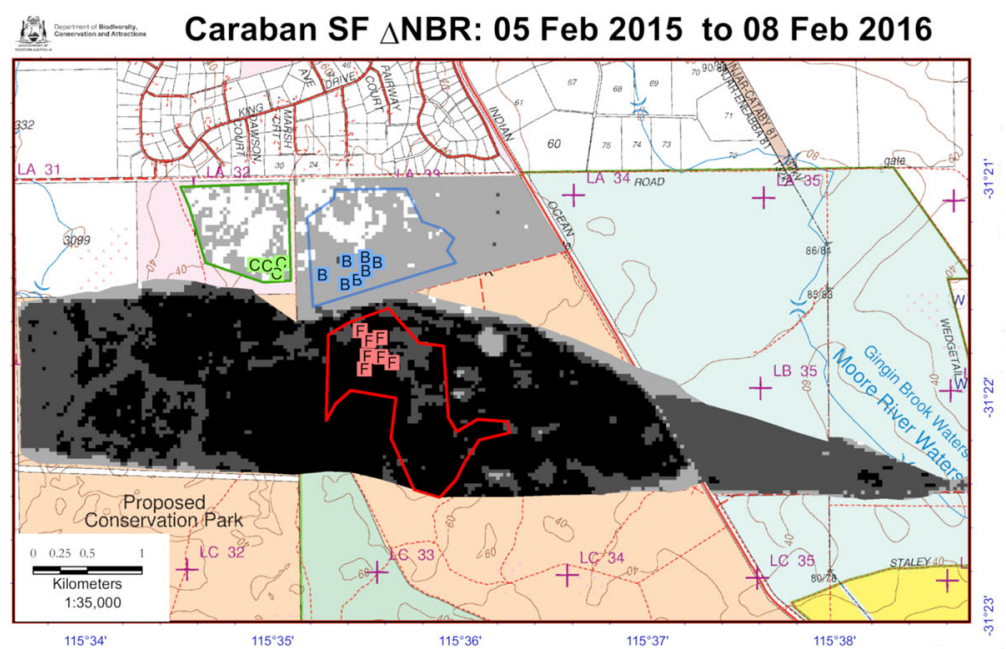

b
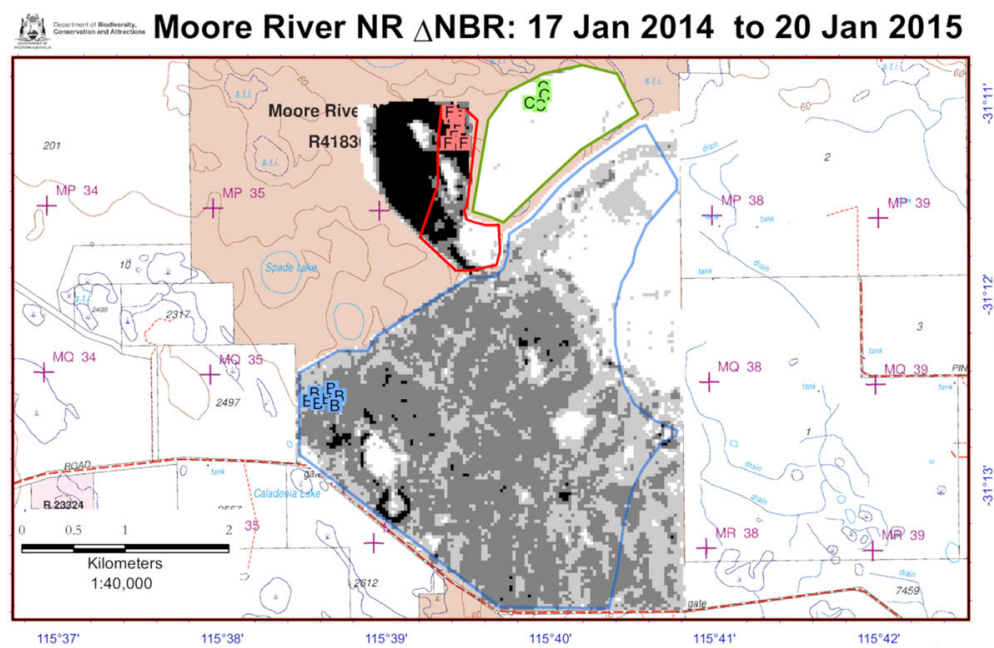

C
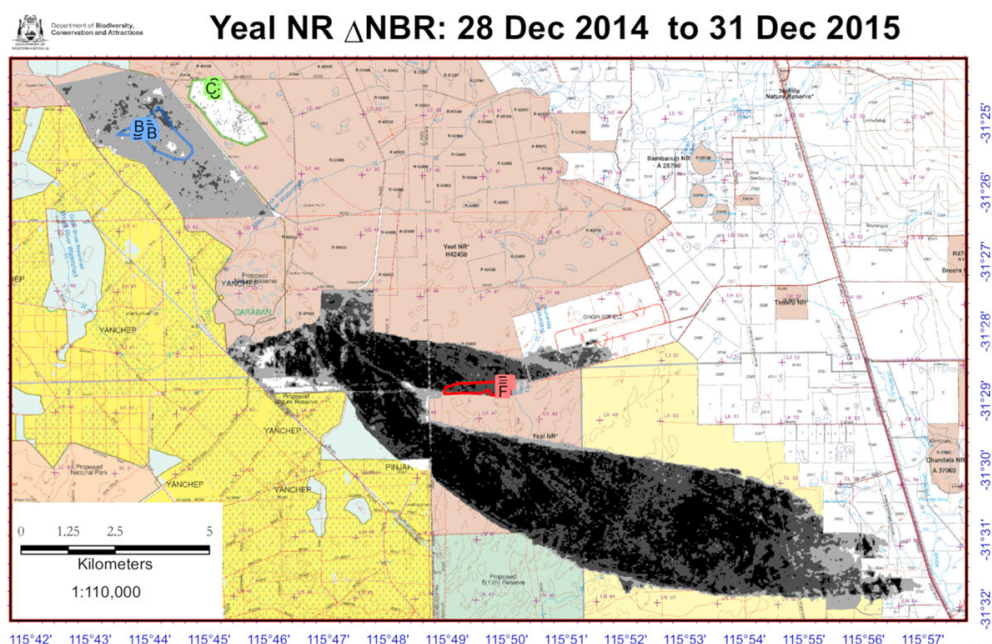

Fig. 1 (See legend on next page.)

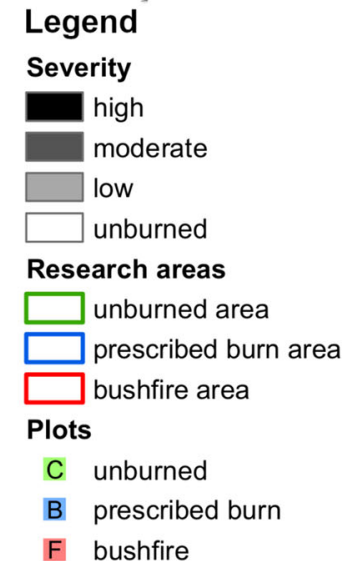

Legend

Severity

high

moderate

low

unburned

Research areas

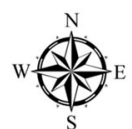


(See figure on previous page.)

Fig. 1 Location of research sites relative to $\triangle$ NBRs in areas affected by prescribed burns, bushfires, or remaining unburned (unburned). The three sets of areas were located in (a) Caraban State Forest, where the prescribed burn occurred on 12 May 2015 and the bushfire occurred on 1 Jan 2016; (b) Moore River Nature Reserve, where the prescribed burn occurred on 9 Oct 2014 and the bushfire occurred on 2 Dec 2014; and (c) Yeal Nature Reserve, where the prescribed burn occurred on 18 Sept 2015 and the bushfire occurred on 22 Nov 2015. The dates of pre- and postevent Landsat 8 images used to derive the $\triangle N B R s$ are provided in each map title. The white box in (c) denotes the location of the research sites within Australia (map subset)

provided an overlap between sites at years 2 and 3. Assessment methodology for this study was adapted from Valentine et al. (2014). Within each site, four (unburned) or seven (prescribed burn and bushfire) $25 \times 25 \mathrm{~m}$ plots were marked using a metal rod for the southwest corner and flagging tape for the remaining corners to provide visibility across the plot. Plot eastings and northings were recorded using a handheld GPS. Fewer plots were located in unburned sites because the hypotheses focused primarily on differences between the burn and fire sites, and values for unburned sites could be compared to published values (i.e., Valentine et al. 2014). The total number and live or dead status of adult ( $>2 \mathrm{~m}$ tall) B. attenuata and B. menziesii individuals were recorded for each plot. Individuals were considered dead if they did not have any live material, such as leaves or flowers, on the branches, stem, or as coppice. Only standing banksias were counted. Banksias near the boundaries were recorded if their stem base occurred entirely within the demarcated area.

In each plot, the total number of cones present on all adult $B$. attenuata and $B$. menziesii adults were recorded. Evidence of foraging (attacked discarded cones and torn flowers) within each plot was also noted. All cones present on each adult banksia were counted in this study, rather than limiting the count to only those cones with closed follicles (Johnston 2013; Valentine et al. 2014). This approach was chosen because the height and canopy dimensions of some adult banksias in long-unburned and burn sites made it difficult to determine if numerous cones in the upper canopy retained closed follicles. Consequently, this study reports a significantly greater number of cones per tree than prior studies.

Subject to the availability of adults in each plot, five cones from each species were collected to count the number of closed and open follicles. Each cone was collected from a separate live individual. This method was chosen to replicate Valentine et al. (2014) to extend the findings from that study. However, cones were chosen at random, rather than choosing only cones with closed follicles as per Johnston (2013) and Valentine et al. (2014) to compensate for the greater number of cones per tree reported in this study. This approach corrected calculations of the number of closed follicles per hectare to be commensurate with Johnston's (2013) data, and calculations of available kilojoules fell within the same range as that reported by Valentine et al. (2014).

\section{Assessing food availability}

The number of cones per tree and closed follicles per cone were averaged for each plot. The weight of seeds produced per hectare was calculated using dry husked seed weights of $0.075 \mathrm{~g}$ for B. attenuata and $0.053 \mathrm{~g}$ for $B$. menziesii (Johnston 2013). To calculate annual carrying

Table 1 Recent fire history for the nine prescribed burn, bushfire, and unburned sites located in three areas on the Swan Coastal Plain north of Perth, Western Australia, Australia, measured each January from 2017 to 2019, inclusive. The date, season, and fuel age when the prescribed burn or bushfire occurred is provided in the initial columns. The total number of bushfires or prescribed burns and seasons when they occurred is then provided. The average interval between bushfires or prescribed burns (events) and the median categories of event type and season are listed in bold text. Burn = prescribed burn, Fire = bushfire, N/A = not applicable, $\mathrm{N} / \mathrm{D}=$ not determined due to insufficient data, NR = Nature Reserve, SF = State Forest

\begin{tabular}{|c|c|c|c|c|c|c|c|c|c|c|c|c|}
\hline \multirow[b]{2}{*}{ Area name } & \multirow{2}{*}{$\begin{array}{l}\text { Event } \\
\text { category }\end{array}$} & \multirow[b]{2}{*}{ Date } & \multirow[b]{2}{*}{ Season } & \multirow{2}{*}{$\begin{array}{l}\text { Fuel age at } \\
\text { event (yr) }\end{array}$} & \multirow{2}{*}{$\begin{array}{l}\text { Average event } \\
\text { interval (yr) }\end{array}$} & \multirow{2}{*}{$\begin{array}{l}\text { Number of } \\
\text { fires recorded }\end{array}$} & \multirow{2}{*}{$\begin{array}{l}\text { Number of } \\
\text { burns recorded }\end{array}$} & \multirow{2}{*}{$\begin{array}{l}\text { Median } \\
\text { category }\end{array}$} & \multicolumn{3}{|c|}{ Number of events per season } & \multirow{2}{*}{$\begin{array}{l}\text { Median } \\
\text { season }\end{array}$} \\
\hline & & & & & & & & & Spring & Summer & Autumn & \\
\hline \multirow[t]{3}{*}{ Yeal NR } & Burn & 18 Sep 2015 & Spring & 11 & 12.3 & 0 & 5 & Burn & 2 & 0 & 2 & $\mathrm{~N} / \mathrm{D}$ \\
\hline & Fire & 22 Nov 2015 & Spring & 11 & 11.0 & 2 & 3 & Burn & 3 & 1 & 1 & Spring \\
\hline & Unburned & $\mathrm{N} / \mathrm{A}$ & N/A & N/A & 13.0 & 2 & 3 & Burn & 3 & 2 & 0 & Spring \\
\hline \multirow[t]{3}{*}{ Caraban SF } & Burn & 12 May 2015 & Autumn & 10 & 8.2 & 3 & 4 & Burn & 2 & 4 & 1 & Summer \\
\hline & Fire & 01 Jan 2016 & Summer & 11 & 10.0 & 4 & 2 & Fire & 2 & 4 & 0 & Summer \\
\hline & Unburned & N/A & N/A & N/A & 9.5 & 4 & 1 & Fire & 1 & 4 & 0 & Summer \\
\hline \multirow[t]{3}{*}{ Moore River NR } & Burn & 09 Oct 2014 & Spring & 12 & 12.0 & 1 & 1 & N/D & 1 & 1 & 0 & $\mathrm{~N} / \mathrm{D}$ \\
\hline & Fire & 02 Dec 2014 & Summer & 12 & 12.0 & 2 & 0 & Fire & 0 & 2 & 0 & Summer \\
\hline & Unburned & $\mathrm{N} / \mathrm{A}$ & $\mathrm{N} / \mathrm{A}$ & $\mathrm{N} / \mathrm{A}$ & 14.0 & 1 & 0 & Fire & 0 & 1 & 0 & Summer \\
\hline
\end{tabular}


Table 2 Weather conditions and fire behavior parameters for the prescribed burns and bushfires that occurred on the Swan Coastal Plain north of Perth, Western Australia, Australia, that were studied from 2017 through 2019 to compare resulting availability of seed from B. attenuata and B. menzeseii. Note that the rates of spread listed are for headfire; flank fires spread at approximately half the headfire rate of spread. Burn = prescribed burn, Fire = bushfire, NR = Nature Reserve, SF = State Forest, Rh= Relative humidity

\begin{tabular}{|c|c|c|c|c|c|c|c|c|}
\hline Area name & Type & $\begin{array}{l}\text { Date } \\
\text { commenced }\end{array}$ & $\begin{array}{l}\text { Forecast } \\
\text { maximum } \\
\text { temperature } \\
\left({ }^{\circ} \mathrm{C}\right)\end{array}$ & $\begin{array}{l}\text { Forecast } \\
\text { minimum Rh } \\
(\%)\end{array}$ & $\begin{array}{l}\text { Forecast wind } \\
\text { direction; speed } \\
\left(\mathrm{km} \mathrm{h}^{-1}\right)\end{array}$ & $\begin{array}{l}\text { Fuel loads } \\
\left(\mathrm{t} \mathrm{ha}^{-1}\right)\end{array}$ & $\begin{array}{l}\text { Headfire rate of } \\
\text { spread range } \\
\left(\mathrm{m} \mathrm{h}^{-1}\right)\end{array}$ & $\begin{array}{l}\text { Intensity range } \\
\left(\mathrm{kW} \mathrm{m}^{-1}\right)\end{array}$ \\
\hline Moore River NR & Fire & 02 Dec 2014 & 28 & 23 & ESE to $S W ; 10$ to 25 & 8.6 to 10.9 & 500 & 2150 to 2725 \\
\hline Moore River NR & Burn & 09 Oct 2014 & 22 & 43 & SW to SSW; 15 to 25 & 6.6 to 8.4 & 60 to 150 & 198 to 630 \\
\hline Yeal NR & Fire & 22 Nov 2015 & 38 & 13 & NE to WNW; 20 to 35 & 16.1 to 19.1 & 1500 to 8000 & 12075 to 76400 \\
\hline Yeal NR & Burn & 18 Sep 2015 & 26 & 37 & WSW; 15 to 25 & 10.1 to 13.1 & 60 to 150 & 303 to 983 \\
\hline Caraban SF & Fire & 01 Jan 2016 & 35 & 20 & $\mathrm{E}$ to ESE; 20 to 45 & 9.0 to 10.8 & 1000 to 4000 & 4500 to 21600 \\
\hline Caraban SF & Burn & 12 May 2015 & 24 & 38 & $\mathrm{E}$ to $\mathrm{ENE} ; 15$ to 25 & 7 to 8.8 & 60 to 150 & 210 to 660 \\
\hline
\end{tabular}

capacity per hectare, seed weights per hectare were summed for B. attenuata and B. menziesii and $17.267 \mathrm{ki}-$ lojoules per gram $\left(\mathrm{kJ} \mathrm{g}^{-1}\right)$ were used for both species (Stock et al. 2013). A foraging threshold, or giving-up density, was set at 97 cones $\mathrm{ha}^{-1}$; harvesting rate or foraging waste was set at $80 \%$; and metabolization rate was $80 \%$. The annual energy requirement for a Carnaby's cockatoo was estimated at $175.5 \mathrm{MJ}$ (Williams et al. 2017).

\section{Statistical analyses}

Data collected two and three years following the prescribed burns and bushfires were analyzed using a generalized linear mixed-effects model (glmer) for the negative binomial regression with the glmer. nb function from the lme4 package version 1.1-21 in $\mathrm{R}$ version 3.5.1 (Bates et al. 2015; R Core Team 2018). Negative binomial regression was chosen both to allow for overdispersion in the dependent count variables and because graphs indicated that the plot variances were quadratic to the plot means for counts of live or dead trees, cones per live tree, and closed follicles per cone (Ver Hoef and Boveng 2007). The effect of treatment and possible interactions between treatment and year were analyzed, and area was included as a random crossed variable. The glmer . nb function fit the glmer model by maximum likelihood using the Laplace approximation applied to the random effects of the integrated likelihood (Vonesh 1996). The proportion of live trees compared to both live and dead trees was analyzed using beta regression with the betareg function in the betareg package (Cribari-Neto and Zeileis 2010).

The type II analysis of deviance function from the car package was used on each regression model to detect any differences $(\alpha \leq 0.050)$. When only a treatment effect was found significant, estimated marginal means from the emmeans package were used post-hoc with a Sidak method to adjust the confidence level, and Tukey method (Day and Quinn 1989) to adjust $P$ values for comparing a family of three estimates. When a significant interaction between treatment and year was detected, contrasts between estimated marginal means were used with a Tukey method to adjust $P$ values (Mangiafico 2016).

\section{Results}

Intensity and severity of prescribed burns versus bushfires

The prescribed burns produced markedly lower ranges of fire intensity compared to the bushfires (Table 2). Differenced normalized burn ratios $(\triangle \mathrm{NBRs})$ suggested that $20 \%$ or more area on average experienced moderate- or high-severity fire from bushfires compared to prescribed burns (Fig. 2). A few pixels in the unburned sites were classified as low- or moderate-severity fire, providing a guide to the overall accuracy of $\triangle \mathrm{NBR}$, which is normally equivalent to or slightly less than $80 \%$ (Cocke et al. 2005).

\section{Survival of $B$. attenuata and B. menziesii}

Over 25\% more banksias survived a low-intensity prescribed burn compared to a high-intensity bushfire (estimated coefficient [est] $=0.21, P<0.01)$. Prescribed burning did not decrease the percentage of banksias that survived compared to unburned sites (est $=0.01, P=0.94$; Table 3). The higher survival rates were due to over $60 \%$ more live $B$. attenuata (est $=0.49, P<0.01$ ) and $B$. menziesii (est $=0.88, P<0.01$ ) adults in sites that experienced a prescribed burn compared to a bushfire (Table 3). Although a trend was apparent for more dead adult banksias following a bushfire, the effect was only significant compared to unburned sites (est $=-0.94, P=0.047$ ).

\section{Amplitude of disturbance for cone production}

Cone production was significantly reduced following bushfire for $B$. menziesii, but not for $B$. attenuata (Table 3). Banksia menziesii produced over 60\% less cones per hectare two and three years after bushfire compared to prescribed burn (est $=1.06, P<0.01$ ) or unburned sites (est $=1.06, P<0.01$ ). No differences in cones per tree or per hectare for either Banksia species 


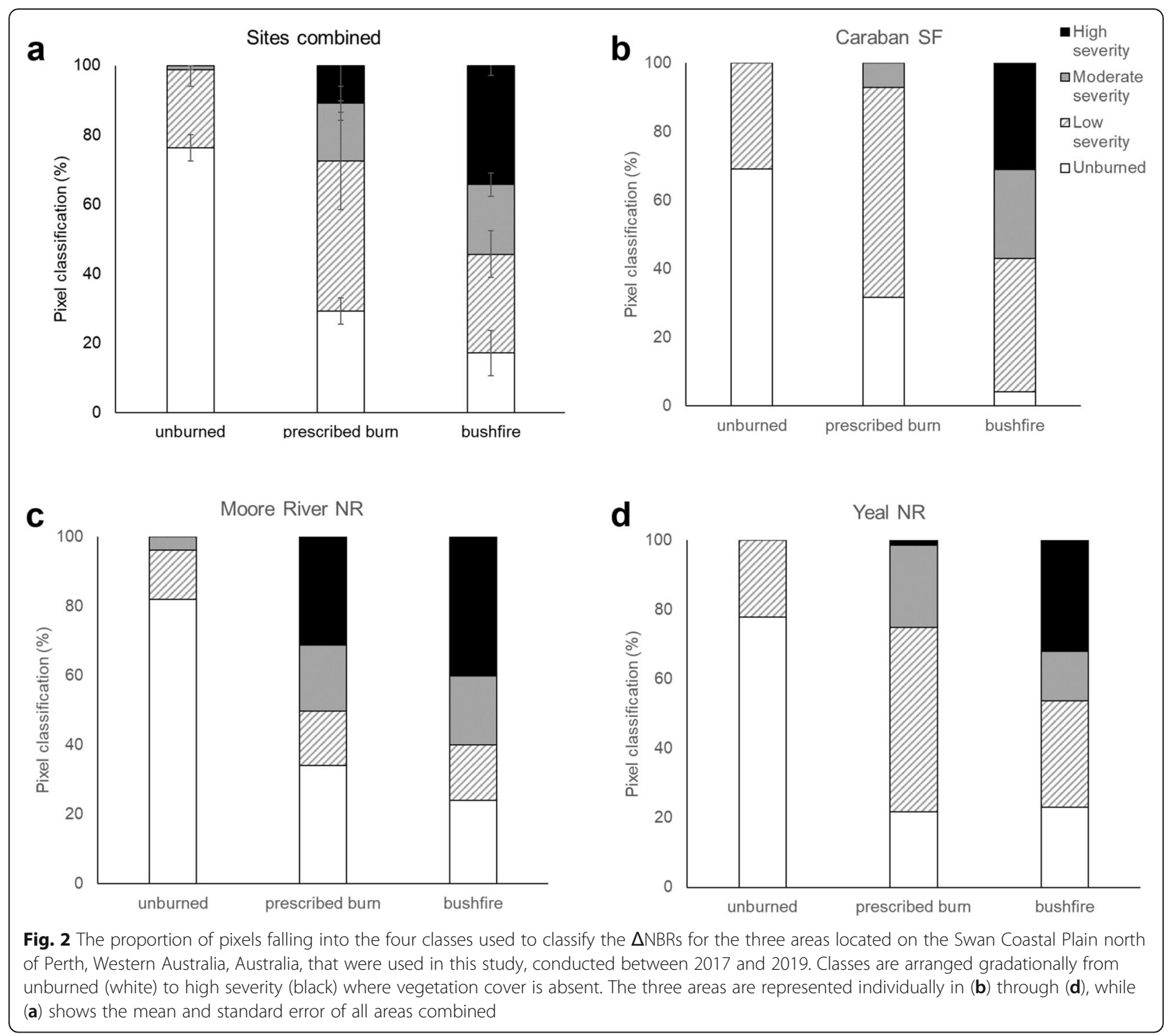

were detected between prescribed burn and unburned sites (est $=-0.01, P=0.99$ ).

\section{Resilience of seed availability}

Seed availability for $B$. attenuata and $B$. menziesii showed significantly greater resilience following prescribed burning compared to bushfire (Table 3). Prescribed burning did not significantly reduce the number of closed follicles per cone for either $B$. attenuata (est = $0.08, P=0.86$ ) or $B$. menziesii (est $=0.35, P=0.55$ ) compared to unburned sites. After bushfire, $B$. attenuata cones had $50 \%$ fewer closed follicles compared to $B$. attenuata cones from prescribed burn (est $=0.77, P<$ 0.01 ) or unburned sites (est $=0.85, P<0.01$ ). Banksia menziesii cones showed a $90 \%$ reduction in closed follicles two years after bushfire compared to unburned sites (est $=1.46, P<0.01$ ) and over $85 \%$ fewer closed follicles than prescribed burn sites (est $=1.11, P<0.01$ ). The number of closed follicles per $B$. menziesii cone appeared to be nearing pre-fire levels by three years after bushfire, but a significant interaction between treatment and year was not detected.

Closed follicles contain an average of 1.09 and 1.27 seeds for $B$. attenuata and B. menziesii, respectively, while open follicles usually lack seeds due to seed release. Therefore, the amount (grams) of seed available per hectare could be estimated with some confidence. Prescribed burning did not decrease the production of seed for B. attenuata (est $=0.08, P=0.86$ ) or $B$. menziesii (est $=0.88, P=0.26$ ) compared to unburned sites. Sites affected by bushfire had around 2.5 times less seed mass from $B$. attenuata (est $>0.77, P<0.01$ ) and $B$. menziesii (est $>2.83, P<0.01$ ) compared to both prescribed burn and unburned sites (Table 3). 
Table 3 The numbers of B. attenuata and B. menzeseii adult trees and cones per hectare, closed follicles per cone, and estimated grams of seed per hectare and carrying capacity for Carnaby's cockatoo compared among banksia woodland sites located 30 to 50 km north of Perth, Western Australia, from 2017 through 2019. Sites were chosen from paired areas that had been treated with a prescribed burn, experienced a bushfire, or remained unburned. The mean and standard error (italicized number below the mean) are provided. Treatments not sharing the same letter are different for that year at $a \leq 0.05$

\begin{tabular}{|c|c|c|c|c|c|c|}
\hline & \multicolumn{2}{|l|}{ Unburned } & \multicolumn{2}{|c|}{ Prescribed burn } & \multicolumn{2}{|l|}{ Bushfire } \\
\hline & Year 2 & Year 3 & Year 2 & Year 3 & Year 2 & Year 3 \\
\hline \multirow[t]{2}{*}{ Live $B$. attenuata trees (trees $\mathrm{ha}^{-1}$ ) } & $138.7^{\mathrm{a}, \mathrm{b}}$ & $113.3^{a, b}$ & $171.4^{\mathrm{a}}$ & $158.5^{\mathrm{a}}$ & $102.1^{b}$ & $108.2^{b}$ \\
\hline & 26.8 & 24.5 & 22.4 & 18.0 & 17.1 & 15.2 \\
\hline \multirow[t]{2}{*}{ Live B. menzeseii trees (trees $\mathrm{ha}^{-1}$ ) } & $73.3^{\mathrm{a}}$ & $89.3^{\mathrm{a}}$ & $101.3^{\mathrm{a}}$ & $89.9^{\mathrm{a}}$ & $33.5^{\mathrm{b}}$ & $46.5^{b}$ \\
\hline & 15.1 & 15.9 & 13.9 & 11.1 & 7.9 & 10.8 \\
\hline \multirow[t]{2}{*}{ Total live trees $\left(\right.$ trees $\mathrm{ha}^{-1}$ ) } & $212.0^{a, b}$ & $202.7^{a, b}$ & $272.8^{\mathrm{a}}$ & $248.4^{\mathrm{a}}$ & $135.6^{b}$ & $154.7^{b}$ \\
\hline & 34.2 & 30.7 & 28.2 & 22.0 & 21.2 & 23.1 \\
\hline \multirow[t]{2}{*}{ Total dead trees (trees ha ${ }^{-1}$ ) } & $18.7^{\mathrm{a}}$ & $13.3^{\mathrm{a}}$ & $32.0^{a, b}$ & $18.4^{\mathrm{a}, \mathrm{b}}$ & $49.5^{b}$ & $38.9^{b}$ \\
\hline & 5.1 & 4.7 & 7.4 & 4.9 & 16.4 & 7.6 \\
\hline \multirow[t]{2}{*}{ Survival (\%) } & $90.7^{\mathrm{a}}$ & $94.0^{a}$ & $89.2^{\mathrm{a}}$ & $92.5^{\mathrm{a}}$ & $66.7^{\mathrm{b}}$ & $71.1^{\mathrm{b}}$ \\
\hline & 2.5 & 2.1 & 2.7 & 1.8 & 7.0 & 6.7 \\
\hline \multirow[t]{2}{*}{ B. attenuata cones (cones ha ${ }^{-1}$ ) } & 6122.7 & 5158.7 & 5697.5 & 5049.1 & 3995.4 & 4868.6 \\
\hline & 934.9 & 708.4 & 810.4 & 586.7 & 912.7 & 1188.3 \\
\hline \multirow[t]{2}{*}{ B. menzeseii cones (cones ha ${ }^{-1}$ ) } & $1741.3^{\mathrm{a}}$ & $2354.7^{\mathrm{a}}$ & $1849.1^{\mathrm{a}}$ & $1712.0^{\mathrm{a}}$ & $554.7^{\mathrm{b}}$ & $626.3^{b}$ \\
\hline & 452.7 & 817.9 & 339.9 & 315.2 & 248.5 & 255.1 \\
\hline \multirow[t]{2}{*}{ B. attenuata closed follicles (follicles cone ${ }^{-1}$ ) } & $4.0^{\mathrm{a}}$ & $3.8^{\mathrm{a}}$ & $3.2^{\mathrm{a}}$ & $4.1^{\mathrm{a}}$ & $1.4^{\mathrm{b}}$ & $2.1^{b}$ \\
\hline & 0.8 & 0.6 & 0.3 & 0.4 & 0.4 & 0.5 \\
\hline \multirow[t]{2}{*}{ B. menzesii closed follicles (follicles cone ${ }^{-1}$ ) } & $2.1^{\mathrm{a}}$ & $1.9^{\mathrm{a}}$ & $1.4^{\mathrm{a}}$ & $1.6^{\mathrm{a}}$ & $0.2^{\mathrm{b}}$ & $1.4^{\mathrm{a}}$ \\
\hline & 0.8 & 0.7 & 0.3 & 0.4 & 0.1 & 0.6 \\
\hline \multirow[t]{2}{*}{ B. attenuata seed $\left(\mathrm{g} \mathrm{ha}^{-1}\right)$} & $2069.5^{\mathrm{a}}$ & $1480.5^{\mathrm{a}}$ & $1556.1^{\mathrm{a}}$ & $1896.7^{\mathrm{a}}$ & $384.7^{b}$ & $891.5^{b}$ \\
\hline & 515.5 & 281.9 & 307.0 & 327.5 & 124.4 & 390.1 \\
\hline \multirow[t]{2}{*}{ B. menzesii seed $\left(\mathrm{g} \mathrm{ha}^{-1}\right)$} & $194.4^{\mathrm{a}}$ & $436.5^{\mathrm{a}}$ & $245.2^{\mathrm{a}}$ & $222.1^{\mathrm{a}}$ & $12.1^{\mathrm{b}}$ & $64.2^{b}$ \\
\hline & 68.5 & 239.8 & 78.3 & 64.7 & 9.0 & 31.2 \\
\hline \multirow[t]{2}{*}{ Carnaby's cockatoo (100 ha $\left.\mathrm{hr}^{-1}\right)$} & $14.1^{\mathrm{a}}$ & $11.8^{\mathrm{a}}$ & $11.1^{\mathrm{a}}$ & $13.1^{\mathrm{a}}$ & $2.5^{\mathrm{b}}$ & $5.9^{b}$ \\
\hline & 3.1 & 2.2 & 2.0 & 2.1 & 0.8 & 2.5 \\
\hline
\end{tabular}

Sites that were treated with prescribed burn or were unburned could potentially support over $75 \%$ more Carnaby's cockatoos than bushfire-affected sites (est $>1.26$, $P<0.01$; Table 3). Prescribed burning did not significantly affect potential carrying capacity for Carnaby's cockatoo compared to unburned sites (est $=0.13, P=0.84$ ).

\section{Discussion}

This study found minimal disturbance to survival or seed production after prescribed burning for either $B$. attenuata or B. menziesii. Conversely, bushfire significantly reduced both the proportion of adult banksias that survived and their seed production for at least two to three years compared to sites that remained unburned or had experienced a prescribed burn. Comparative assessments of fire behavior and maps of fire severity indicated that fire intensity was markedly greater during bushfire than prescribed burning. This supports the hypothesis that fire intensity affects the resilience of seed production by $B$. attenuata and $B$. menziesii, and the broader argument that multiple components of the fire regime influence ecological outcomes rather than timesince-fire in isolation. More specifically, this study supports the use of prescribed burning as a conservation tool in banksia woodland, an MCR.

The high rates of survival suggest that low intensity burning does not constrain the average age of the banksia canopy to the surrounding fuel age. Previous studies have reported that few or no banksias are killed due to prescribed burning (Baird 1977; Lamont 1985; Enright and Lamont 1989; Hobbs and Atkins 1990). Prescribed burning is more likely to remove a short understory rather than the midstory or canopy strata (Baird 1977; Lamont et al. 1995; Hodgkinson 2002; Sitters et al. 2015). Removing the understory can temporarily reduce resource competition (Gill 1975), which may enhance growth 
(Stewart et al. 1993) and seed production (Stock et al. 1989). Proteaceae species have demonstrated higher abundance following low or moderate fire intensities compared to high fire intensity (Enright and Lamont 1989; Hobbs and Atkins 1990; Roche et al. 1998; Morrison 2002). Thus, banksia species may be more likely to reach full maturity and optimal seed production when prescribed burning mitigates the risk of a stand-replacing bushfire (Burrows and McCaw 1990; Burrows et al. 2008; Boer et al. 2009).

Previous studies have found that the amount of cones produced by $B$. attenuata and B. menziesii correlate significantly to plant allometry and time-since-fire. A key assumption has been that all fire in banksia woodland is generally sufficient to scorch the canopy and is often stand replacing (Johnston 2013; Valentine et al. 2014; Wilson et al. 2014). Full scorch delays flowering in Banksia species for two years (Lamont 1985), and canopy size and volume significantly affect cone production for B. attenuata and B. menziesii (Johnston 2013). Newly germinated $B$. attenuata seedlings require four years before flowering (Lamont 1985), and B. attenuata and B. menziesii reach optimum seed production around 16 to 20 and 11 to 15 years post fire, respectively (Johnston 2013; Valentine et al. 2014). Tolerable fire intervals for banksia woodland have also been estimated at 16 years, based on twice the average time necessary for obligate seeding species to set seed (Burrows et al. 2008; Wilson et al. 2014). However, this study found a significantly different amplitude of disturbance between low-intensity prescribed burns and high-intensity bushfires. Prescribed burns were significantly less likely to scorch the canopy and permitted flowering and cone production to continue at a similar rate to age-matched sites that remained unburned. Bushfires were found to significantly reduce cone and seed production for at least three years. This disturbance to seed production may extend for well over a decade after bushfire (Burrows et al. 2008; Johnston 2013; Valentine et al. 2014), compounding the loss of seed production after bushfire relative to low-intensity prescribed burning.

Population sizes of Carnaby's cockatoo were not measured in this study, but the two Banksia species monitored represent an important food resource that is reasonably expected to affect the population dynamics of these cockatoos (Johnston 2013; Valentine et al. 2014; Williams et al. 2017). The resilience of birds to fire in a variety of other vegetation types has been closely linked to recovery of habitat variables, particularly cover and food availability. Neutral or positive responses were common when fires were of sufficiently low severity to leave the midstory and canopy predominantly intact (Smucker et al. 2005; Fontaine and Kennedy 2012; Lindenmayer et al. 2014; Sitters et al. 2015). Recovery times for bird populations were often shorter following low-intensity fire than after high- intensity fire (Lindenmayer et al. 2014). The amplitude of fire disturbance to bird populations was also greater in vegetation types that had a simple vertical structure, such as heath rather than forest (Barton et al. 2014). Structural complexity in MCRs has been related to fire frequency (Cowling et al. 1996), but fire regime and regeneration strategies also play a key role (Baird 1977; Burrows et al. 2010; Sitters et al. 2015).

This study illustrates the importance of considering multiple components of the fire regime to determine the resilience of species following fire. By including fire intensity as well as fire interval, this study confirmed and extended work by Johnston (2013) and Valentine et al. (2014) by finding that bushfire markedly reduced seed availability, but that prescribed burning did not have a significant effect compared to long-unburned sites.

It is widely accepted that species can persist in flammable ecosystems largely because they possess traits adapted to the inherent fire regime. Frequency, extent, seasonality, and intensity are interconnected parameters that together define a fire regime. Prescribed burns are conducted to manage intensity and extent by applying fire at selected seasons and intervals within geographical boundaries. Bushfires typically occur during warm, dry seasons that support a high intensity and uniform application of fire often over a large area. Thus, bushfires and prescribed burns generally represent divergent fire regimes that promote different responses by the in situ species (Whight and Bradstock 1999; Morrison 2002; Vesk and Westoby 2004; Lawes et al. 2015; Sitters et al. 2015). It is highly recommended that fire ecology studies distinguish between bushfire and prescribed burns to avoid producing confounded data.

Land management practices in flammable MCRs need to incorporate appropriate fire regimes to promote conservation of endemic species. Prescribed burning represents a useful tool to minimize disturbance caused by unplanned bushfire, particularly when high-intensity bushfires are typically stand-replacing events. To conserve viable populations of Carnaby's cockatoo, it is necessary to maintain or increase areas that contain productive $B$. attenuata and $B$. menziesii adults, particularly as the population size of banksia stands may affect seed set (Lamont et al. 1995). Prescribed burning produces a mosaic of lower intensities, including unburned patches, compared to a more uniform high intensity typical of bushfires in banksia woodland (Wilson et al. 2010). Thus, prescribed burning is recommended as current best practice to maintain food stocks that would otherwise be susceptible to bushfire (Wilson et al. 2010).

\section{Conclusions}

These results suggest that using prescribed burning to mitigate the risk of bushfire is a viable strategy to 
preserve a critical food resource for the endangered Carnaby's cockatoo. This study found that prescribed burning had a markedly different effect on banksia seed availability than bushfire. Survival of adult banksias and their production of follicles were significantly greater during the first few years after prescribed burn compared to bushfire. Differenced normalized burn ratios and rates of spread indicated that bushfire produced a much higher intensity fire than prescribed burning that sufficiently limited fire severity to sustain the availability of banksia seed in banksia woodland canopy. Consequently, carrying capacity for Carnaby's cockatoo by banksia seeds was the same between unburned sites and those treated with prescribed burns. The time frame examined in this study was short, and it is important to continue monitoring these areas in successive years to determine whether the initial results persist over the long term. Future research into this or related areas should include a strong focus on fire intensity as well as time-since-fire to understand the recovery processes following bushfires or prescribed burns. Regardless, these results have important ramifications for land management within banksia woodland, namely that prescribed burning may support rather than harm banksia and cockatoo populations.

\section{Acknowledgements}

L. Sage (DBCA) gave valuable feedback on the study design and manuscript and provided access and resources to help collect the data. P. Rampant (DBCA) provided satellite imagery and instruction to produce $\triangle$ NBRs. J. Fontaine (Murdoch University) and B. Miller (King's Park Botanic Gardens) were instrumental to help design the approach, locate field sites, and provide feedback on the manuscript. N. Burrows (DBCA) and L. McCaw (DBCA) gave invaluable feedback on the manuscript.

\section{Authors' contributions}

VSD designed the study, selected study areas, collected and analyzed data, and wrote the manuscript. ESC substantially helped refine methods and collect and analyze data. Both authors read and approved the final manuscript.

\section{Funding}

Funding was not provided external to the Department of Biodiversity, Conservation and Attractions, Western Australia, which requested that a study of this nature be undertaken but otherwise did not play a significant role in study design, data collection, data analysis and interpretation, or manuscript writing.

\section{Availability of data and materials}

The datasets used and analyzed during the current study are available from the corresponding author on reasonable request.

\section{Ethics approval and consent to participate}

Not applicable.

\section{Consent for publication}

This manuscript has been approved for publication by Biodiversity and Conservation Science Division and the District Fire Coordinator at Swan Coastal District, where this study was undertaken.

\section{Competing interests}

Both V.D. and E.C. have or currently work in Fire Management Services within DBCA and have written and implemented burn prescriptions and helped suppress bushfires.

\section{Author details}

'Department of Biodiversity, Conservation and Attractions, Manjimup Research Centre, Locked Bag 2, Manjimup, Western Australia 6258, Australia. ${ }^{2}$ Department of Biodiversity, Conservation and Attractions, Swan Coastal

District, 5 Dundebar Road, Wanneroo, Western Australia 6030, Australia.

Received: 24 February 2019 Accepted: 28 August 2019

Published online: 28 October 2019

\section{References}

Baird, A.M. 1977. Regeneration after fire in King's Park, Perth, Western Australia. Journal of the Royal Society of Western Australia 60: 1-22.

Barton, P.S., K. Ikin, A.L. Smith, C. MacGregor, and D.B. Lindenmayer. 2014. Vegetation structure moderates the effect of fire on bird assemblages in a heterogeneous landscape. Landscape Ecology 29 (4): 703-714 https://doi.org/ 10.1007/s10980-014-0017-z.

Bates, B.C., P. Hope, B. Ryan, I. Smith, and S. Charles. 2008. Key findings from the Indian Ocean Climate Initiative and their impact on policy development in Australia. Climatic Change 89 (3-4): 339-354 https://doi.org/10.1007/s10584007-9390-9.

Bates, D., M. Machler, B. Bolker, and S. Walker. 2015. Fitting linear mixed-effects models using Ime4. Journal of Statistical Software 67 (1): 1-48 https://doi.org/ 10.18637/jss.V067.i01.

Boer, M.M., R.J. Sadler, R.S. Wittkuhn, L. McCaw, and P.F. Grierson. 2009. Long-term impacts of prescribed burning on regional extent and incidence of wildfires-evidence from 50 years of active fire management in SW Australian forests. Forest Ecology and Management 259: 132-142 https://doi. org/10.1016/j.foreco.2009.10.005

Brundrett, M., R. van Dongen, B. Huntley, N. Ta, and V. Longman. 2018. A monitoring toolkit for banksia woodlands: comparison of different scale methods to measure recovery of vegetation after fire. Remote Sensing in Ecology and Conservation 5 (1): 33-54 https://doi.org/10.1002/rse2.88.

Burrows, N., B. Ward, and A. Robinson. 2010. Fire regimes and tree growth in low rainfall jarrah forest of south-west Australia. Environmental Management 45: 1332-1343 https://doi.org/10.1007/s00267-010-9490-6.

Burrows, N.D., and W.L. McCaw. 1990. Fuel characteristics and bushfire control in banksia low woodlands in Western Australia. Journal of Environmental Management 31: 229-236 https://doi.org/10.1016/S0301-4797(05)80036-2.

Burrows, N.D., G. Wardell-Johnson, and B. Ward. 2008. Post-fire juvenile period of plants in south-west Australia forests and implications for fire management. Journal of the Royal Society of Western Australia 91: 163-174.

Byram, G.M. 1959. Forest fire behavior. In Forest fire: control and use, ed. K.P. Davis, 90-123. New York: McGraw-Hill.

Cocke, A.E., P.Z. Fulé, and J.E. Crouse. 2005. Comparison of burn severity assessments using differenced Normalized Burn Ratio and ground data. International Journal of Wildland Fire 14: 189-198 https://doi.org/10.1071/WF04010.

Cooper, C.E., P.C. Withers, P.R. Mawson, S.D. Bradshaw, J. Prince, and H. Roberston. 2002. Metabolic ecology of cockatoos in the south-west of Western Australia. Australian Journal of Zoology 50 (1): 67-76 https://doi.org/10.1071/ZO00067.

Cowling, R.M., and B.B. Lamont. 1985. Variation in serotiny of three Banksia species along a climatic gradient. Australian Journal of Ecology 10 (3): 345350 https://doi.org/10.1111/j.1442-9993.1985.tb00895.x.

Cowling, R.M., B.B. Lamont, and S.M. Pierce. 1987. Dynamics of four co-occurring Banksia species. Journal of Ecology 75 (2): 289-302 https://doi.org/10.2307/2260419.

Cowling, R.M., P.W. Rundel, B.B. Lamont, M.K. Arroyo, and M. Arianoutsou. 1996. Plant diversity in mediterranean-climate regions. Trends in Ecology \& Evolution 11 (9): 362-366 https://doi.org/10.1016/0169-5347(96)10044-6.

Cribari-Neto, F., and A. Zeileis. 2010. Beta regression in R. Journal of Statistical Software 34 (2): 1-24 https://doi.org/10.18637/jss.V034.102.

Day, R.W., and G.P. Quinn. 1989. Comparisons of treatments after an analysis of variance in ecology. Ecological Monographs 59 (4): 433-463 https://doi.org/ 10.2307/1943075

Enright, N.J., and B.B. Lamont. 1989. Seed banks, fire season, safe sites and seedling recruitment in five co-occurring Banksia species. Journal of Ecology 77 (4): 1111-1122 https://doi.org/10.2307/2260826.

Fontaine, J.B., and P.L. Kennedy. 2012. Meta-analysis of avian and small-mammal response to fire severity and fire surrogate treatments in US fire-prone forests. Ecological Applications 22 (5): 1547-1561 https:/doi.org/10.1890/12-0009.1.

Gill, A.M. 1975. Fire and the Australian flora: a review. Australian Forestry 38 (1): 425 https://doi.org/10.1080/00049158.1975.10675618. 
Gill, A.M. 1978. Adaptive responses of Australian vascular plant species to fires. In Fire and the Australian biota, ed. A.M. Gill, R.H. Groves, and I.R. Noble, 244272. Canberra: Australian Academy of Science.

Heddle, E.M., D.W. Longeragan, and J.J. Havel. 1980. Vegetation complexes of the Darling System, Western Australia. In Atlas of natural resources, Darling System, Western Australia, 37-72. Perth: Department of Conservation and Environment.

Hobbs, R.J., and L. Atkins. 1990. Fire-related dynamics of a Banksia woodland in south-western Western Australia. Australian Journal of Botany 38 (1): 97-110 https://doi.org/10.1071/BT9900097.

Hodgkinson, K.C. 2002. Fire regimes in Acacia wooded landscapes: effects on functional processes and biological diversity. In Flammable Australia. The fire regimes and biodiversity of a continent, ed. R.A. Bradstock, J.E. Williams, and A. M. Gill. Cambridge: Cambridge University Press.

Hutto, R.L., and D.A. Patterson. 2016. Positive effects of fire on birds may appear only under narrow combinations of fire severity and time-since-fire. International Journal of Wildland Fire 25 (10): 1074-1085 https://doi.org/10. 1071/WF15228.

Jenks, G.F. 1967. The data model concept in statistical mapping. International Yearbook of Cartography 7: 186-190.

Johnston, T.R. 2013. Food resource availability for Carnaby's cockatoo Calyptorhynchus latirostris on the Swan Coastal Plain. Thesis. Edith Cowan University, Western Australia, Australia.

Johnston, T.R., W.D. Stock, and P.R. Mawson. 2016. Foraging by Carnaby's blackcockatoo in Banksia woodland on the Swan Coastal Plain, Western Australia. Emu - Austral Ornithology 116 (3): 284-203 https://doi.org/10.1071/MU15080.

Keeley, J.E. 1986. Resilience of mediterranean shrub communities to fires. In Resilience in mediterranean-type ecosystems. Tasks for vegetation science, volume 16, ed. B. Dell, A.J.M. Hopkins, and B.B. Lamont, 95-111. Dordrecht: Springer https://doi.org/10.1007/978-94-009-4822-8_7.

Keeley, J.E. 2009. Fire intensity, fire severity and burn severity: a brief review and suggested usage. International Journal of Wildland Fire 18 (1): 116-126 https://doi.org/10.1071/WF07049.

Lamont, B. 1985. Fire responses of sclerophyll shrublands-a population ecology approach, with particular reference to the genus Banksia. In Fire ecology and management in Western Australia. Report No. 14, ed. J. Ford, 41-46. Perth: Western Australia Institute of Technology Environmental Studies Group.

Lamont, B.B., R.T. Wills, and E.T.F. Witkowski. 1995. Threats to the conservation of southwestern Australian Proteaceae. Acta Horticulturae 387: 9-18 https://doi. org/10.17660/ActaHortic.1995.387.1.

Lavorel, S. 1999. Ecological diversity and resilience of Mediterranean vegetation to disturbance. Diversity and Distributions 5 (1-2): 3-13 https://doi.org/10. 1046/j.1472-4642.1999.00033.x.

Lawes, M.J., B.P. Murphy, A. Fisher, J.C.Z. Woinarski, A.C. Edwards, and J. Russell-Smith. 2015. Small mammals decline with increasing fire extent in northern Australia: evidence from long-term monitoring in Kakadu National Park. International Journal of Wildland Fire 24 (5): 712-722 https://doi.org/10.1071MF14163.

Lindenmayer, D.B., W. Blanchard, L. McBurney, D. Blair, S.C. Banks, D.A. Driscoll, A. L. Smith, and A.M. Gill. 2014. Complex responses of bird to landscape-level fire extent, fire severity and environmental drivers. Diversity and Distributions 20 (4): 467-477 https://doi.org/10.1111/ddi.12172.

Mangiafico, S.S. 2016. Summary and analysis of extension program evaluation in R. http://rcompanion.org/handbook/. Accessed 19 Apr 2019.

McCaw, L., and B. Hanstrum. 2003. Fire environment of mediterranean southwest Western Australia. In Fire in ecosystems of south-west Western Australia: impacts and management, ed. I. Abbott and N. Burrows, 87-106. Leiden: Backhuys Publishers.

Morrison, D.A. 2002. Effects of fire intensity on plant species composition of sandstone communities in the Sydney region. Austral Ecology 27 (4): 433-441 https://doi.org/10.1046/j.1442-9993.2002.01197.x.

R Core Team. 2018. R: a language and environment for statistical computing. R Foundation for Statistical Computing, Vienna, Austria. https://www.R-project. org/. Accessed 20 Sept 2018.

Roche, S., K.W. Dixon, and J.S. Pate. 1998. For everything a season: smokeinduced seed germination and seedling recruitment in a Western Australian Banksia woodland. Australian Journal of Ecology 23 (2): 111-120 https://doi. org/10.1111/j.1442-9993.1998.tb00709.x

Saunders, D.A. 1980. Food and movements of the short-billed form of the whitetailed black cockatoo. Australian Wildlife Research 7 (2): 257-269 https://doi. org/10.1071/WR9800257.

Shah, B. 2006. Conservation of Carnaby's black-cockatoo on the Swan Coastal Plain, Western Australia. Perth: Birds Australia Western Australia.
Sitters, H., J. Di Stefano, F.J. Christie, P. Sunnucks, and A. York. 2015. Bird diversity increases after patchy prescribed fire: implications from a before-after control-impact study. International Journal of Wildland Fire 24 (5): 690-701 https://doi.org/10.1071/WF14123.

Smucker, K.M., R.L. Hutto, and B.M. Steele. 2005. Changes in bird abundance after wildfire: importance of fire severity and time since fire. Ecological Applications 15 (5): 1535-1549 https://doi.org/10.1890/04-1353.

Sneeuwjagt, R.J., and G.B. Peet. 1985. Forest fire behaviour tables for Western Australia. 3rd ed. Perth: Department of Conservation and Land Management.

Stewart, G.R., J.S. Pate, and M. Unkovich. 1993. Characteristics of inorganic nitrogen assimilation of plants in fire-prone mediterranean-type vegetation. Plant, Cell \& Environment 16 (4): 351-363 https://doi.org/10.1111/j.1365-3040.1993.tb00881.x.

Stock, W.D., H. Finn, J. Parker, and K. Dods. 2013. Pine as fast food: foraging ecology of an endangered cockatoo in a forestry landscape. PLOS ONE 8 (4): e61145 https://doi.org/10.1371/journal.pone.0061145.

Stock, W.D., J.S. Pate, J. Kuo, and A.P. Hansen. 1989. Resource control of seed set in Banksia laricina C. Gardner (Proteaceae). Functional Ecology 3 (4): 453-460 https://doi.org/10.2307/2389619.

Syphard, A.D., V.C. Radeloff, T.J. Hawbaker, and S.I. Steward. 2009. Conservation threats due to human-caused increases in fire frequency in mediterraneanclimate ecosystems. Conservation Biology 23 (3): 758-769 https://doi.org/10. 1111/j.1523-1739.2009.01223.x

Threatened Species Scientific Committee. 2016. Approved conservation advice (incorporating listing advice) for the Banksia woodlands of the Swan Coastal Plain ecological community. Canberra: Department of the Environment and Energy.

Valentine, L.E., R. Fisher, B.A. Wilson, T. Sonneman, W.D. Stock, P.A. Fleming, and R. J. Hobbs. 2014. Time since fire influences food resources for an endangered species, Carnaby's cockatoo, in a fire-prone landscape. Biological Conservation 175: 1-9 https://doi.org/10.1016/j.biocon.2014.04.006.

Van Wilgen, B.W., G.G. Forsyth, H. de Klerk, S. Das, S. Khuluse, and P. Schmitz. 2010. Fire management in mediterranean-climate shrublands: a case study from the Cape fynbos, South Africa. Journal of Applied Ecology 47 (3): 631638 https://doi.org/10.1111/j.1365-2664.2010.01800.x.

Ver Hoef, J.M., and P.L. Boveng. 2007. Quasi-Poisson vs. negative binomial regression: how should we model overdispersed count data? Ecology 88 (11): 2766-2772 https://doi.org/10.1890/07-0043.1

Vesk, P.A., and M. Westoby. 2004. Sprouting ability across diverse disturbances and vegetation types worldwide. Journal of Ecology 92 (2): 310-320 https:// doi.org/10.1111/j.0022-0477.2004.00871.x.

Vonesh, E.F. 1996. A note on the use of Laplace's approximation for nonlinear mixed-effects models. Biometrika 83 (2): 447-452 https://doi.org/10.1093/ biomet/83.2.447

Walz, Y., S.W. Maier, S.W. Dech, C. Conrad, and R.R. Colditz. 2007. Classification of burn severity using Moderate Resolution Imaging Spectroradiometer (MODIS): a case study in the jarrah-marri forest of southwest Western Australia. Journal of Geophysical Research 112: G02002 https://doi.org/10. 1029/2005JG000118.

Whelan, R.J. 1995. The ecology of fire. Melbourne: Cambridge University Press. Whight, S., and R. Bradstock. 1999. Indices of fire characteristics in sandstone heath near Sydney, Australia. International Journal of Wildland Fire 9 (2): 145153 https://doi.org/10.1071/WF00012.

Williams, M.R., C.J. Yates, D.A. Saunders, R. Dawson, and G.W. Barrett. 2017. Combined demographic and resource models quantify the effects of potential land-use change on the endangered Carnaby's cockatoo (Calyptorhynchus latirostris). Biological Conservation 210 (A): 8-15 https://doi. org/10.1016/j.biocon.2017.03.018.

Wilson, B.A., J. Kuehs, and L.E. Valentine. 2010. Guidelines for developing ecological burning regimes for the Gnangara Groundwater System. Report for the Gnangara Sustainability Strategy and the Department of Environment and Conservation. Perth: Department of Water.

Wilson, B.A., J. Kuehs, L.E. Valentine, T. Soneman, and K.M. Wolfe. 2014. Guidelines for ecological burning regimes in mediterranean ecosystems: a case study in Banksia woodlands in Western Australia. Pacific Conservation Biology 20 (1): 57-74 https://doi.org/10.1071/PC140057.

Wooller, S.J., and R.D. Wooller. 2001. Seed set in two sympatric banksias, Banksia attenuata and B. baxteri. Australian Journal of Botany 49 (5): 597-602 https:// doi.org/10.1071/BT00084.

\section{Publisher's Note}

Springer Nature remains neutral with regard to jurisdictional claims in published maps and institutional affiliations. 